\title{
Effectiveness Of Multimedia Elements In Computer Supported Instruction: Analysis Of Personalization Effects, Students' Performances And Costs
}

Mark Zaidel, Northern State University, USA

XiaoHui Luo, Northern State University, USA

\begin{abstract}
This study investigates the efficiency of multimedia instruction at the college level by comparing the effectiveness of multimedia elements used in the computer supported learning with the cost of their preparation. Among the various technologies that advance learning, instructors and students generally identify interactive multimedia elements as very powerful tools, enhancing teaching and learning. However, feasibility of this instruction needs to be further explored because preparing multimedia for computerized learning modules is expensive and time consuming. Furthermore, effectiveness of multimedia depends of the methods and models used for content delivery, and adapting instruction to the diverse learning preferences of students influences the effectiveness of teaching and learning.
\end{abstract}

Keywords: On-line learning, multimedia, educational technologies, effectiveness of content preparation, research in higher education

\section{INTRODUCTION}

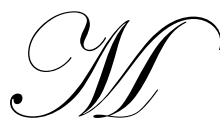

ultimedia elements can provide variety and excitement to a computer-supported teaching and learning environment, adapting instruction to the diverse learning preferences of students. However, preparing instruction, combining elements of online text, hypertext, images, sound, and video, might be expensive and time consuming.

In recent years, the research of computer-supported instruction and learning has increased significantly in universities and colleges (Hassan, 2007). "With the progress on information technologies online instruction became an alternative mode of teaching and learning (Tallent-Runnels, 2006), also increasing instructors confidence in communication (Brown, 2000). Current college students are more familiar with computer-supported technologies and, in some cases, have a better understanding of presented subjects when they interact with flexible computerbased modules (Jereb, 2006; Kurtis, 2003).

The relationship between cost and quality of e-learning instruction in student-centered analyses depends on the individual views of learners as to the importance of different types of interactions (Bramble, 2008, p.138). The curricular benefits of students mainly depend on alignment between learning objectives with learning activities, but production cost of e-learning instruction depends on chosen methods of multimedia delivery (Rumble, 1997, p.79). Finding balance between anticipated benefits of students and the cost of multimedia-driven instruction influences their effectiveness and value in education (Cohen, 2002; Sadik, 2004).

Matching specific learning preferences with different types of multimedia instruction can help learners by providing a comfortable and easy-to-manage learning environment. Some studies conclude that advanced multimedia instruction heightens visual aspects of communication, provides dynamic learning experiences, increases 
learning results and adjusts to learning preferences (Evans, 2007; Wang, 2008). Other studies indicate that traditionally, multimedia elements seem very attractive as teaching tools. However, they do not always provide substantial cognitive benefits for students (Ellis, 2001) and often, they do not make any significant impact on learning and can be costly (Sun, 2007).

A number of learning style models have been developed in the last three decades, including models such as Hill's Cognitive Style Mapping, Dunn \& Dunn learning style, Grasha-Reichmann Learning Style Scales, FelderSilverman Learning Model, and Kolb's Learning Style Inventory (Moallem, 2007). In this study, we have chosen to use Kolb's model because of its quantifiable interpretation and its direct implementation of instructional strategies as they relate to the Accommodating, Diverging, Converging and Assimilating learning styles.

This study investigates a complex relationship between the learner's performance; selected methods of delivery, as defined by used multimedia elements; students' learning preferences and economics of content production. The effectiveness of instruction is assessed in combination with different learning styles, and the combined impact of learning styles, multimedia elements, and their efficiency in student-centered instruction is assessed based on analysis of computer-supported instruction used for an undergraduate natural science course at Northern State University.

\section{METHOD}

Fifty six students participated in the study during the fall and spring semesters of the 2007 academic year at NSU. Four types of computer-supported instruction were designed for a very peculiar undergraduate geography topic. The presentation topic was based on an unknown to students and controversial theory, and it was not necessary to test prior knowledge about the subject that was taught. A 15-question rigorous and very precise multiple-choice quiz was administered to measure students' performance and the effectiveness of instruction.

The custom application program in the 4th Dimension development environment (4th Dimension, 2007) was written to generate web pages, conduct the experiments and collect results. About 70 HTML instructional pages were designed and created, containing hypertext, images, sound and videos, from the instructor and third party materials. Each HTML page was designed in the same size (1024x768 pixels). Four modules of computer-supported instructions were used in this study and were designed according to Kolb's Learning Style Inventory Test (Kolb, 1984) using the following interface templates:

1. Text-Images. This template was designed for Kolb's Assimilating Learning Style and each HTML page contained 12-pixel text and an embedded 480x320 pixel image.

2. Sound-Text. This template was designed for Kolb's Converging Learning Style and each HTML page contained a recorded voice and an embedded 480x320 pixels image.

3. Video. This template was designed for Kolb's Diverging Learning Style and each HTML page contains one video clip and a short textual caption.

4. Text-Interactive. This template was designed for Kolb's Accommodating Learning Style and the typical page for this presentation contained 10-pixels font and three 150x150 pixels thumbnails. Students could click on the thumbnail pictures to see the full size images (480x320 pixels). They also had the option to explore more information by clicking on the hypertext links.

All the preparation of instruction, data entry, and creating web pages took approximately 220 hours (details shown in Table 5).

\section{PROCEDURE}

In the first semester, 29 students were randomly divided into four groups to take on-line presentations as described above. In the following semester, a different group of 27 students took the same instruction. This time students were assigned to participate in specific presentations that matched their learning styles which were determined by a simple Kolb-based Inventory test. During both semesters and after the presentation, students took the same on-line 15-question quiz to measure their performance and the effectiveness of instruction. 
The following information was collected by the application program, communicating with students via Web server: 1) sequence of all pages opened by students during learning session, 2) time spent on each page, and 3) opened interactive links. Students' quiz scores were linked to their learning sessions and analyzed separately for both semesters.

\section{RESULTS}

For each semester, students' performances were assessed by calculating the score of every student's quizzes. Table 1 lists presentations corresponding to the highest and the lowest average scores of students for each semester. The average scores of students' quizzes for each type of presentation are shown in Table 2. Times that students spent studying each type of presentation are shown in Table 3. In order to compare the effectiveness of different types of multimedia presentations and the influence of learning styles, students' performances were analyzed by comparing test results that demonstrated significant dependence of learning styles (results shown in Table 4).

Table 1: Highest and Lowest Test Scores [\%]

\begin{tabular}{|c|c|c|}
\hline Scores & \multicolumn{2}{|c|}{ Instruction } \\
\hline & Without Learning Styles & Using Learning Styles \\
\hline Highest & Text-Interactive (42.0) & Text-Images (41.3) \\
\hline Lowest & Video (23.1) & Video (28.9) \\
\hline
\end{tabular}

Table 2: Average Test Scores Differentiated by Type of Presentation [\%]

\begin{tabular}{|c|c|c|c|c|c|c|c|c|}
\hline Score & \multicolumn{9}{|c|}{ Presentation } \\
\hline & \multicolumn{4}{|c|}{ Without Learning Styles } & \multicolumn{4}{c|}{ Using Learning Styles } \\
\cline { 2 - 10 } & $\begin{array}{c}\text { Text- } \\
\text { Images }\end{array}$ & $\begin{array}{c}\text { Sound- } \\
\text { Text }\end{array}$ & Video & $\begin{array}{c}\text { Text- } \\
\text { Interactive }\end{array}$ & $\begin{array}{c}\text { Text- } \\
\text { Images }\end{array}$ & $\begin{array}{c}\text { Sound- } \\
\text { Text }\end{array}$ & Video & Interactive \\
\hline Average & 40.7 & 28.9 & 23.1 & 42.0 & 41.3 & 40.0 & 28.9 & 32.4 \\
\hline
\end{tabular}

Table 3: Time of Study by Type of Presentation

\begin{tabular}{|c|c|c|c|c|c|c|c|c|}
\hline \multirow{3}{*}{ Time } & \multicolumn{8}{|c|}{ Presentation } \\
\hline & \multicolumn{4}{|c|}{ Without Learning Styles } & \multicolumn{4}{|c|}{ With Learning Styles } \\
\hline & $\begin{array}{c}\text { Text- } \\
\text { Images }\end{array}$ & $\begin{array}{c}\text { Sound- } \\
\text { Text }\end{array}$ & Video & $\begin{array}{c}\text { Text- } \\
\text { Interactive }\end{array}$ & $\begin{array}{c}\text { Text- } \\
\text { Images }\end{array}$ & $\begin{array}{c}\text { Sound- } \\
\text { Text }\end{array}$ & Video & $\begin{array}{c}\text { Text- } \\
\text { Interactive }\end{array}$ \\
\hline Average & $0: 22: 59$ & $0: 17: 22$ & $0: 20: 33$ & $0: 24: 42$ & $0: 21: 27$ & $0: 26: 07$ & $0: 24: 26$ & $0: 25: 42$ \\
\hline Longest & $0: 37: 48$ & $0: 28: 27$ & 0:34:08 & $0: 38: 02$ & 0:34:03 & 0:33:03 & $0: 30: 33$ & $0: 38: 37$ \\
\hline Shortest & $0: 12: 39$ & 0:11:09 & 0:07:31 & $0: 12: 00$ & $0: 15: 57$ & $0: 17: 35$ & $0: 14: 35$ & $0: 22: 43$ \\
\hline
\end{tabular}

Table 4: Discrepancies in Students' Scoring [\%]

\begin{tabular}{|c|c|c|c|c|c|c|c|c|c|}
\hline \multirow{3}{*}{$\begin{array}{c}\text { Ratios of } \\
\text { students (1) } \\
\text { that scored } \\
\text { significantly } \\
\text { higher than } \\
\text { students (2) }\end{array}$} & \multicolumn{4}{|c|}{ Presentation with Learning Styles (1) } & \multirow{3}{*}{$\begin{array}{c}\text { Ratios of } \\
\text { students (2) } \\
\text { that scored } \\
\text { significantly } \\
\text { lower than } \\
\text { students (1) }\end{array}$} & \multicolumn{4}{|c|}{ Presentation with Learning Styles (2) } \\
\hline & $\begin{array}{l}\text { Text- } \\
\text { Image }\end{array}$ & $\begin{array}{c}\text { Sound- } \\
\text { Text }\end{array}$ & Video & $\begin{array}{c}\text { Text- } \\
\text { Interactive }\end{array}$ & & $\begin{array}{l}\text { Text- } \\
\text { Image }\end{array}$ & $\begin{array}{c}\text { Sound- } \\
\text { Text }\end{array}$ & Video & $\begin{array}{c}\text { Text- } \\
\text { Interactive }\end{array}$ \\
\hline & 14 & 0 & 28 & 51 & & 25 & 17 & 25 & 60 \\
\hline
\end{tabular}

Table 5 presents time spent on preparing and developing specific presentations and the estimated hourly cost for each presentation. Calculations are based on the hours spent on content development, media preparation, interface design/development, the creation of presentations and testing. Hourly expenses were based only on the average labor cost of $\$ 40 / \mathrm{hr}$., not including institutional overhead. 
Table 5: Production Time and Cost Analysis for One-hour Presentations

\begin{tabular}{|l|c|c|c|c|}
\hline \multicolumn{1}{|c|}{ Tasks } & \multicolumn{4}{c|}{ Presentations } \\
\cline { 2 - 5 } & Text-Images & Sound-Text & Video & Text-Interactive \\
\hline $\begin{array}{l}\text { Subject/content collection for on-line } \\
\text { instruction [hours], divided equally }\end{array}$ & 20 & 20 & 20 & 20 \\
\hline Interface design [hours] & 10 & 11 & 7 & 14 \\
\hline $\begin{array}{l}\text { Content preparation [hours]: text, sound, } \\
\text { video, images }\end{array}$ & 9 & 12 & 48 & \multirow{2}{*}{12} \\
\hline Testing and tuning [hours] & 3 & 4 & 6 & 4 \\
\hline Time for all on-line tasks [hours] & 22 & 27 & 84 & 30 \\
\hline Total hours for all tasks & 42 & 47 & 2,560 & 50 \\
\hline Cost of on-line preparations [dollars] & 880 & 1,080 & 3,360 & 2,200 \\
\hline Total cost [dollars] & 1,680 & 1,880 & & 2,000 \\
\hline
\end{tabular}

\section{DISCUSSION}

Independently of presence or absence of learning styles in prepared instruction, students taking the video presentations had the lowest scores. When instruction was not aligned with the learning styles, students receiving a text-interactive presentation scored higher than others. However, when instruction was aligned with learning styles, students receiving a text-image presentation obtained the best scores. In general, students who took presentations matching their learning styles scored much higher than students who took presentations without learning styles considered.

The detail analysis of data from individual students taking video presentations shown that some students watched a video presentation for less than 15 minutes, regardless of the fact that the whole video presentation was approximately 30 minutes. These students also obtained the lowest results on the test. Therefore, it could be concluded that using videos in computer-supported instruction does not improve students' performances in comparison with other types of presentations.

Based on the results in Table 2, students receiving the text-images, sound-text and video presentations had higher scores when presentation type matched their learning style. One could conclude that using text, images, sound, and video in computer-supported instruction has much more positive effects on students' performances when it is combined with students' learning preferences; similar conclusions were presented in earlier studies (Lam, 2006; Sanders 2005), but similarly to other studies (Veronikas, 2005) we fund that instructional applications of some multimedia elements such as sound or video not always increase students' learning achievements.

The average, longest and shortest times that individual students spent on each presentation are shown in Table 3. Results suggest that when learning styles of students were matched with corresponding presentations, students were more motivated, spending significantly more time on studying. In order to compare the effectiveness of different types of multimedia presentations and the influence of learning styles, students' performances were analyzed (results shown in Table 4). For example, when learning styles were not used, only $29 \%$ of the students scored significantly higher in the text-images presentation than students whose presentation matched their learning styles. These positive outcomes follow similar pattern as Koroghlanian's study applying multimedia instruction in biology (Koroghlanian, 2004). On the other hand, when presentations were matched with learning styles, only $25 \%$ of the students scored significantly lower in the text-image presentation than students taking the same presentation, but not matched with their learning styles.

The costs associated with multimedia courseware development are based on a number of factors. The biggest factor in development cost is the amount of time it takes to complete the project. The amount of time includes preparation of the subject/content collection for on-line instruction, interface design, data entry and digitization, testing, and tuning. In this study, the one-hour cost was calculated as an average of all elements; i.e., instructional and on-line production. As shown in Table 5, the one-hour video presentation was the most expensive with a cost of $\$ 3,360$. On the other hand, the one-hour Text-Image presentation had the lowest cost of $\$ 1,680$. 
This study demonstrates that the video presentations are expensive and, in our study, have not improved students' performances. In conclusion, video presentations were not cost effective when compared with other types of presentations and student performances. Multimedia-rich instructions are more appealing to students but, overall, they do not offer higher curricular gain at the college level than other types of computer-supported instruction. In contrast, text-based instruction was much more affordable and led to better performance of students.

\section{ACKNOWLEDGEMENT}

We thank Dr. William Hoar for his creative comments about our on-line presentations and letting us conduct experiments in his class.

\section{AUTHOR INFORMATION}

Mark Zaidel in educator and researcher in subjects of electronic learning, including information processing and retrieval, knowledge discovery from contextual data, computer-supported instruction, autonomous learning objects, human-computer interactions, software design, networking and computer hardware. In the business world he focuses on implementations of information systems, e-commerce and applications of operation research in data processing. Mark Zaidel holds MS in Mathematics, Ph.D in Operation Research, he is senior faculty and coordinator of elearning graduate program at Northern State University in Aberdeen, SD, USA.

Hiao Hui Luo graduated from NSU at spring of 2008 with the MS degree in E-learning Technology. Her interests relate to multimedia applications, content preparation, and effectiveness of teaching in on-line environment.

\section{REFERENCES}

1. Bramble, W.J., Panda, S. (2008). Economics of Distance and On-line Learning: Theory, Practice and Research. New York, NY: Routledge, Taylor \& Francis Group.

2. Brown, D.C. (2000). Interactive learning. Bolton, MA: Anker Publishing Company, INC.

3. Cohen, M.S., Ellis, T.J. (2002). Developing a criteria set for an online learning environment. Proceedings: Frontiers in Education Conference, November 6-9, Boston, MA, pp.T3E-8-T3E-13

4. Ellis, T., Cohen, M. (2001). Integrating multimedia into a distance learning environment: is the game worth the candle? British Journal of Education Technology, 32, 495-498. Retrieved February 14, 2008, from Academic Search Complete.

5. Evans, C., Gibbons, N.J. (December, 2007). The inveracity effect in multimedia learning. Centre for Education Multimedia, 49(4), 1147-1160. Retrieved February 20, 2008, from Academic Search Complete.

6. Fourth Dimension (software system). (2007). http://en.wikipedia.org/wiki/4th_Dimension_(software)

7. Hassan, B. N., Sushil, C., Osman, A., Worth, P. J. (November, 2007). Engineering education: web-based interactive learning resources. Technology Teacher, 67(3), 9-14. Retrieved February 4, 2008, from Academic Search Complete.

8. Jereb, E., Smitek, B. (2006). Applying multimedia instruction in e-learning. Innovation in Educational and Teaching International, 43, 15-28. Retrieved February 1, 2008, from ProQuest Smart Search.

9. Koroghlanian, C., Klein, J. P. (2004). The effect of audio and animation in multimedia instruction. Journal of Educational Multimedia and Hypermedia, 13(1), 24-47. Retrieved on February 15, from ProQuest Smart Search.

10. Lam, P., McNaught, C. (September, 2006). Design and evaluation of online courses containing mediaenhancing learning materials. Educational Media International, 43(3), 199-218. Retrieved February 20, 2008, from Academic Search Complete.

11. Moallem, M. (2007). Accommodating individual differences in the design of online learning environments: a comparative study. Journal of Research on Technology in Education, 40(2), 217-245. Retrieved February 8, 2008, from Academic Search Complete.

12. Rumble, G. (1997). The cost and economics of open and distance learning. London: Routledge-Falmer.

13. Sadik, A., Reisman, S. (2004). Design and implementation of a web-based learning environment. Quarterly Review of Distance Education, 5(3), 157-171. Retrieved on Mar.1, from Academic Search Complete. 
14. Sanders D. (2005). Multimedia Enhancements for African American History Course: Challenges and Rewards; 21st Annual Conference on Distance Teaching and Learning Madison, Wisconsin, 2005

15. Sun, P.C., Cheng, H.S. (2007). The design of instructional multimedia in e-learning: a media richness theory-based approach. Computers \& Education, 49 (3), 662-676. Retrieved February 20, 2008, from Academic Complete Search.

16. Veronikas, S. W., Maushak, N. (2005). Effectiveness of audio on screen captures in software application instruction. Journal of Education of Multimedia and Hypermedia, 14, 199-206. Retrieved: February 12, 2008, from ProQuest Smart Search.

17. Wang, L. (2008). Developing and evaluating an interactive multimedia instructional tool: Learning outcomes and user experiences of optometry students. Journal of Educational Multimedia and Hypermedia, 17, 43-58. Retrieved February 11, 2008, from ProQuest Smart Search.

\section{NOTES}

